\title{
ARCHETYPICAL ASPECTS OF HERO IMAGE IN MODERN UKRAINIAN NON-INSTITUTIONAL MILITARY DISCOURSE
}

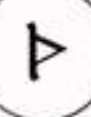

\author{
Tetyana KHRABAN, \\ Candidate of Philological Science, \\ Head of the Department of Foreign \\ Languages \\ E-mail: Xraban.Tatyana@gmail.com, \\ https://orcid.org/0000-0001-5169-5170 \\ Military Institute of Telecommunications \\ and Information Technologies, \\ Moskovska Street, 45/1, Kyiv, 01011 \\ (Kyiv, Ukraine).
}

\section{Citation:}

Khraban, T. \& Silko O. (2021). Archetypical Aspects of Hero Image in Modern Ukrainian Non-

Institutional Military Discourse. Social

Communications: Theory and Practice, Vol. 12(1), 83-97.

DOI: $10.51423 / 2524-0471-2020-12-1-2$

Retrieved from

https://new.comteka.com.ua/index.php/journal/arti

cle/view/80

(C) Khraban T., 2021

$$
\text { (c) EY }
$$

Attribution 4.0 International (CC BY 4.0)

\section{ANNOTATION}

The aim of the article is to study the specifics of the archetypal aspects of the Hero image in modern Ukrainian non-institutional military discourse. Materials \& methods. Discourse analysis was used to identify the characteristics of archetypal images and motifs. The application of psychoanalytic interpretation, the most characteristic feature of which is the accentuation of senses and the assumption of the self-sufficiency of experience, has directed attention to the symbolism of the unconscious, universal meanings and psychological mechanisms inherent in the text. The material for the article was text fragments, photos and comments to them with a total volume of 912 units, which were posted during 2020 on the pages of the social network groups Facebook "Military service - Military Service", "Armed Forces of Ukraine". Results \& discussions. Hero-rescuer mythological archetype is at the heart of the Ukrainian noninstitutional military discourse. Permanent mythological plot can be traced in the military discourse. Thus, the typical stages of the mythological Hero odyssey were observed: the beginning of the mythological Hero's adventures is provoked by a catastrophe, which is caused by criminal actions of his enemies; the Hero sets off for a journey to restore the broken harmony; the villains prevent but the Hero passes the trials and wins his reward. His triumph can be represented as the liberation of his country from tyrant. Addressing the mythological plot carries a pragmatic purpose to overcome stress: the military needs unshakable faith in happy end of the problem situation (military conflict in eastern Ukraine) and the idea of mythological Hero helps soldiers to increase self-confidence. Thus, the Ukrainian non-institutional military discourse shows a relationship between the call to the mythological consciousness and coping strategies. Then, there is tendency observed in the military discourse that Hero archetypal image deviates from the archaic archetype framework and the Hero model with an emphasis on the Christian eschatological paradigm dominates. The motif of sacrifice accompanying the Hero image forms the archetypal image of the Hero-holy man. Conclusion. Two Hero models dominate in the Ukrainian non-institutional military discourse. The first model is distinguished by exaggeration. It is a Hero-superman image defined by similarity to mythological heroes, 
gods, titans. However, this Hero model is not only always accepted by the Ukrainian military but can sometimes arise rejection and protest against Hero-superman image. The second model is a collective image of Ukrainian culture. The People's Hero model actualizes the features of a toiler who is not a professional soldier, he is a peaceful man. This archetypal image is distinguished by realism and contrast to the Hero-superman image.

Key words: Hero archetype, archetypal image, non-institutional military discourse.

\title{
АРХЕТИПІЧНІ АСПЕКТИ ОБРАЗУ ГЕРОЯ В СУЧАСНОМУ УКРАЇНСЬКОМУ НЕІНСТИТУЦЙНОМУ ВІЙСЬКОВОМУ ДИСКУРСІ
}

\author{
Тетяна ХРАБАН, \\ кандидат філологічних наук, \\ завідувач кафедри іноземних мов \\ Військового інституту телекомунікацій та інформатизації \\ (м. Київ, Украӥна)
}

\section{Вступ.}

В умовах сучасної воєнно-політичної ситуації в Україні однією зі значних тенденцій гуманітарних досліджень $є$ зростання інтересу до військового дискурсу. У рамках соціолінгвістики та психолінгвістики особливий інтерес представляє неінституційний військовий дискурс як «особливий вид організації військового дискурсу, що містить емоційно-оцінну, розмовно-побутову інтерпретацію військових подій, реалій і осіб і який характеризується активною суб'єктивною комунікативною інтеракцією» (Уланов, 2014). Оскільки «дискурс - соціальна практика» (Dirven et al, 2005), то військовий дискурс належить насамперед до соціального виміру війни (Ищенко, 2007: 22). При такому підході будь-яке висловлювання розглядається як продукт діяльності соціальних агентів, завжди включених у соціальні взаємодії і структури, конкретну політичну й культурно-історичну ситуацію, тобто як соціальна дія (Огієнко, 2012: 100). 3 іншого боку, соціальні практики характеризуються когнітивним виміром (знання, думки, вірування, норми й цінності, переконання й стереотипи тощо) (Ищенко, 2007: 22), такі поняття, як «колективна пам'ять», «уявлювана спільнота», $є$ невід'ємними категоріями когнітивних процесів (Heеr et al, 2003). Таким чином, «ми аналізуємо та розуміємо історичні сенси як реалії сьогодення через детермінуючу роль як соціальних ознак, що виступають в якості характеристик суб'єктів, так і різноманітних психічних феноменів, що представляють глибинні структури їхнього несвідомого, зокрема й архетипи» (Боровицька, 2013: 82). У сучасному контексті центральне місце в розумінні особистості належить архетипу Герой, який супроводжує значущі етапи історичного розвитку (Иванов, 2019: 80), а також мотивам боротьби й звільнення, супутнім даному архетипові. Актуальність вивчення архетипу Герой підтверджується тим, що «фігура героя є стрижневим елементом багатьох соціальних процесів в сучасному суспільстві, оскільки є засобом представлення суті того, що відбувається» (Суравнева \&Федоров, 2008: 83).

Аналіз останніх досліджень $і$ публікаиій. Архетип Герой досліджувався насамперед у рамках психоаналітичної теорії, тому для цієї статті інтерес представляють класичні роботи, які вивчали цей архетип та його різні модифікації: «The origins and history of consciousness» (Neumann, 1954), «The hero with a thousand faces» (Campbell, 1949), «The 
hero and the outlaw: building extraordinary brands through the power of archetypes» (Mark \& Pearson, 2001). Оскільки рамки дослідження феномена архетипів - це широка міждисциплінарна область, значимими для даного є дослідження в галузі соціології, психології, лінгвістики, а саме: В. Склейниса (Склейнис, 2019) (досліджено внутрішньоособистісні та міжособистісні семантичні структури, що є релевантними для поняття «архетип»); Я. Бугерко (Бугерко, 2013) (схарактеризовано антиномічні особливості феноменів ментальності, культури, ідентичності, через які виявляється архетип, їх зв'язок із рефлексивною здатністю людини аналізувати об'єктивну реальність психічного, яка притаманна несвідомому); О. Гордійчука (Гордійчук, 2018) (проаналізовано особливості формування архетипів української ментальності та їх вплив на соціокультурні явища й суспільно-політичне життя); S. Shadraconis (Shadraconis, 2013) (досліджено значущість архетипів у сучасній ідеалізації лідерів як героїв) та інші. Незважаючи на значну кількість робіт, присвячених дослідженню архетипічних феноменів, у цій статті вперше було звернено увагу на визначення місця, ролі й значення архетипу Герой у сучасному українському неінституціональному військовому дискурсі. Наукова цінність дослідження полягає в подальшому розвитку теорії архетипів у взаємозв'язку з модусами менталітету й ідентичності, що дає можливість осмислити, як на формування соціальних уявлень про героїзм впливає величезна кількість різних факторів (епоха, політика держави, соціальні пріоритети, економічний стан суспільства тощо), але із психолінгвістичної точки зору найцікавішим $є$ вплив соціальних мереж, настільки популярних у наш час.

Mета статті - дослідження специфіки архетипічних аспектів образу Героя в сучасному українському неінституційному військовому дискурсі.

\section{Методи й методики дослідження}

У дослідженні було використано дискурс-аналіз, відправною точкою якого $\epsilon$ твердження про те, що «ми отримуємо доступ до реальності за допомогою мови. За допомогою мови ми створюємо репрезентації реальності, що не просто відображають те, що в ній $\epsilon$, але і конструюють іiі» (Jorgensen \& Phillips, 2002). Іншими словами, «мова - це не просто канал передачі інформації про явища, факти або про поведінку людей, а «механізм», який генерує і конституює соціальний мир» (Jorgensen \& Phillips, 2002). Категорія «дискурс» окреслює такі базові виміри: лінгвістичні й нелінгвістичні, глобальні соціокультурні й індивідуально-особистісні, стабільно-змістові та ситуаційно-динамічні, які поєднані цілісним комунікативним актом (Савелюк, 2017: 48). Як зазначає Teun A. van Dijk, дискурс - це не тільки лінгвістична практика, оскільки він перебуває всередині соціальної практики й сам по собі є соціальною практикою, що сприяє формуванню соціальних систем, ситуацій, інституцій та ідеологій, у які вона закладена (Teun A. van Dijk, 2014), тобто ключовим моментом «виступає соціальна, комунікативна природа людини, що реалізується через її взаємодію із соціумом у семіотичному, зокрема, мовному середовищі життєдіяльності» (Савелюк, 2017:10). Розглядуючи дискурс як складноструктуровану комунікативно-знакову систему, що має декілька основних планів аналізу (Шевченко, 2012), науковий інтерес цієї статті спрямований на дослідження таких ракурсів: 1) актуального (утілення інтенцій у знаково-символічний простір дискурсу); 2) ідентифікуючого (розпізнавання та розуміння смислів, цінностей, побудова ідентичності); 3) контекстуального (розширення смислового поля на основі соціокультурних, історичних та інших контекстів). При цьому осмислення текстів у 
мовних (соціальних) ситуаціях грунтується на «ситуації спілкування і цілого ряду екстралінгвістичних чинників, аж до широкого соціокультурного контексту» (Кожина, 2002: 21-22). У цьому ракурсі дискурсивний підхід дозволяє досліджувати також цілепокладання ідеології в суспільстві, що насичує все полотно дискурсу, оскільки комунікація й дискурс передають культурні моделі, засновані на специфічних елементах і феноменах (Лазарев \& Ласкова, 2020: 103).

Включення в дискурс-аналіз факторів широкого діапазону, соціальних, психологічних, прагматичних тощо, вимагає також використання в стратегії дослідження психоаналітичної інтерпретації як наукового методу психоаналізу. Психоаналітична інтерпретація як особлива пізнавальна установка, найбільш характерними рисами якої $€$ акцентуація смислів і допущення самодостатності переживання, або досвіду, акцентує увагу на закладеній у тексті символіці несвідомого, універсальних значеннях і психологічних механізмах. Психоаналітична інтерпретація включає два етапи - розуміння й пояснення розуміння (Martin, 1990). Розуміння передбачає врахування специфіки форми активного відображення в психіці суб'єкта (групи) об'єктивної дійсності. Розуміння часто пов'язано 3 певним «описом» сутності людини й суспільства. Шляхом пояснення дослідник намагається на науковій основі дати раціональне й логічне тлумачення думок, дій і вчинків суб'єкта (групи). На другому етапі - поясненні розуміння - сплановані або вчинені дії розглядаються в ракурсі причинності, тобто вони аналізуються крізь призму мотивації. Пояснення вважається правильним, якщо причини (стимули), зазначені в поясненні, не тільки існували, але ще й були продуктивними. Пояснення розуміння є не просто формальним (механічним) процесом пошуку мотивації, а й включає в себе оцінку (Martin, 1990; Keil, 2006). Використання психоаналітичної інтерпретації при дослідженні складних, системних об’єктів, що включають людину як елемент, дозволяє значно розширити діапазон дослідження: «психоаналітична інтерпретація розкриває багаторівневу структуру детермінант людського існування, підкреслює епістемологічну важливість унікальних умов існування об'єкта, що аналізується, його суб'єктивних, внутрішніх закономірностей, обумовлених особистісними переживаннями і оцінками, підкреслює принципову важливість динамічних характеристик системи, важливість іi комплексного аналізу» (Доброродний, 2009: 166-167).

Матеріалом для статті послужили текстові фрагменти, фотографії й коментарі до них загальним обсягом 912 одиниць, які розміщені на сторінках груп соціальної мережі Facebook «Military service - Військова служба», «Збройні Сили України» протягом 2020 року.

Методичні обмеження дослідження.

Результати аналізу відображають специфіку архетипічних аспектів образу Героя лише в онлайн-дискурсі. У дослідженні не були враховані погляди людей, які не мають акаунтів у соціальної мережі Facebook.

Крім того, дослідження не враховує ситуацію, коли користувачі соціальних мереж мають різні інтереси й організовують несхожі мережеві співтовариства 3 особливими моделями структури взаємодії між індивідами або групами індивідів. Дослідження проводилося в рамках тільки двох груп: «Military service - Військова служба» і «Збройні Сили України», оскільки в наповненні цих груп акцентуються питання геополітичного, військового й ідеологічного протистояння, що актуалізує образ Героя.

Дослідження не відображає зміни архетипічних аспектів образу Героя в часі, оскільки воно грунтується на матеріалі, яке було викладено на сторінках груп соціальної мережі Facebook протягом одного року. 


\section{Теоретичне підгрунтя дослідження}

Найбільш значущою для даного дослідження $\epsilon$ теорія архетипів, яка була запропонована C. Jung. C. Jung стверджував, що є набір універсальних тем і мотивів, які він назвав архетипами, або диспозиціями в колективному несвідомому, які формують образи у свідомості (Jung, 1968) і завдяки яким здійснюється раціональний вимір свідомого (реальної дії) (Боровицька, 2013). При цьому архетипи - це не самі образи, а схеми образів, їх психологічні передумови, їх можливість (Юрій \& Алексієвець, 2017: 17). Коли ми бачимо реальну людину, стикаємося з будь-якою ситуацією або подією, у нас виникають потужні архаїчні образи, що з'являються з колективного несвідомого. Ці образи викликають сильну емоційну реакцію, яка є не зрозумілою для суб'єкта (Schlegel et al., 2011). Сучасні теорії архетипів стверджують, що результатом емоційної реакції, що виникає при знайомстві з архетипним образом, $є$ безумовне усвідомлення важливості цього персонажа, причому архетипічні моделі передаються шляхом культурної трансмісії, а не біологічним шляхом, як спочатку стверджував С. Jung (McAdams, 2008; Guo \& Ma, 2018). Сучасні реалії гармонійно поєднуються з архаїчним архетипом, набуваючи нових форм (Гоц, 2017: 56). Архетипи на рівні підсвідомості «впливають на світобачення й світорозуміння, забезпечують зв'язок між поколіннями, визначають подальші вектори суспільного розвитку. Грунтовне дослідження архетипів певного народу дозволяє сформувати об'єктивне уявлення про його менталітет» (Гордійчук, 2018: 18). Не слід забувати, що архетип «має суб’єктивне навантаження, адже він продукується активністю конкретної особи і практично не існує поза нею, він інтегрується з ії актуальним досвідом та цілісністю психічного» (Яценко, 2011: 16). Для суб'єкта архетип стає базисом «ідентифікації себе на особистісному, соціальному, національному, расовому рівнях» (Процик, 2009: 62).

\section{Результати та дискусії}

Ключову роль у сучасному українському неінституційному військовому дискурсі відіграє архетип Герой. Тема екзистенціальної свободи, що закладена в архетипі Герой, під час військового конфлікту на Сході України набуває характеру боротьби за незалежність країни. Це сприяло тому, що у військовому дискурсі цей архетип дістає форму соціального архетипу, тобто виступає як «стійка, повторювана і законовідповідна система цілей, цінностей і змістів, що народжується в колективному досвіді на підставі внутрішньої єдності соціальних практик» i «реалізується в різних сферах буття суспільства, тобто у сфері когнітивного, релігійно-етичного, художньо-естетичного, політико-правового, господарсько-економічного і практичного» (Юрій \& Алексієвець, 2017: 19). Архетипні форми не є статичними патернами, застиглими структурами, $\epsilon$ нескінченна кількість модифікацій архетипу Герой, але при будь-якому перетворенні Герой одержує тріумфальну перемогу над злом, нещастями або важким завданням, він доводить свою перевагу на полі битви або в будь-якому іншому місці, де труднощі або виклики вимагають його мужніх й енергійних дій (Mark \& Pearson, 2001). У сучасному українському неінституційному військовому дискурсі простежується стійкість міфологічного сюжету, «так як міфологічні структури складають ядро світогляду особистості, тісно переплітаючись з її цінностями та ідеалами. Вони заглиблюються своїм корінням в підсвідомість, зачіпають ірраціональну сферу особистості, пї глибинні структури, сферу інстинктів, потреб, бажань» (Воеводина, 2012: 51). Найпоширенішим сюжетом різних міфологій є боротьба Героя з інфернальними силами, «яка в той же самий 
час актуалізує кращі його якості, поразка в цій сутичці має далекосяжні наслідки для подальшого розвитку і трансформації світу» (Воеводина, 2012: 51). У військовому дискурсі були відзначені типові дієві етапи одіссеї міфологічного Героя (Campbell, 1949): початок пригод міфологічного Героя провокує катастрофа, яка є наслідком злочинних дій недоброзичливців (Горько пахло польнью, ветер дылм разносил, а по всей Украине - сотни свежих могил... Скорбный звон похоронный. Набегала слеза... У святых на иконах погрустнели глаза) (FB, 2020). Герою необхідно відправитися в подорож із метою відновлення порушеної гармонії (Это - старая повесть, так былало не раз...Не позволила совесть свой нарушить приказ, не дала оставаться от беды в стороне...) (FB, 2020). Злозичливці діють усупереч (Hy а доля - злодійка вража, збавляється, як божевільна) (FB, 2020), але Герой проходить шлях випробувань (Ти бачив жах, кривавий морок; I, почорнілі, втомлені, сплять у степу під ГРАДами) (FB, 2020) і завойовує свою нагороду. Його тріумф може бути представлений як визволення свого народу від тирана (За можливість лишатися вільними...) (FB, 2020). Міфологічний архетип Героя-рятівника лежить в основі сюжетних моделей, що представлені в українському неінституційному військовому дискурсі (Та відвернути від дітей те пекло, з тисячі смертей...) (FB, 2020). Також на зв'язок архетипної форми Героя з міфологічним сюжетом указують міфологічні символи, які відзначають український неінституційний військовий дискурс. Міфологічні символи сприяють ціннісно-смисловому наповненню військового дискурсу. Найбільш часто в ролі міфологічних символів фігурують маркери світових релігій, наприклад: містичні істоти (Химери, демони, примари війні поклони віддають) (FВ, 2020), християнська алегорія святості (дощем впадуть криваві хмари, святих у пекло поведуть...) (FВ, 2020), пекло та рай (И вошли мы в этот ад, где друзей мы многих потеряли!) (FB, 2020), а також маркери біди, зла, злочинних намірів, зради (Це не війна, страшна хвороба, мов чорна пляма на душі; Той дивний сон... Зі зміями боровся...) (FB, 2020), військової доблесті, мужності й відваги (Ви тримали небо, лищарі-герої!) (FВ, 2020). На наш погляд, звернення до міфологічного сюжету в українському неінституційному військовому дискурсі не $\epsilon$ випадковим. Саме в такому ракурсі в архетипі Герой актуалізується адаптаційний потенціал, так необхідний у сучасний час для українських військових. Дане твердження грунтується на факті, що міфи, що розглядаються як когнітивні структури, $є$ позараціональним знанням: люди керуються міфами, у які вірять, $\mathrm{i}$ завдяки їм вони долають негативні емоції шляхом позитивного переосмислення проблемної ситуації. Для подолання стресу військовим необхідна впевненість у щасливому розв'язанні проблемної ситуації (військового конфлікту на Сході України), i міфологічний Герой допомагає їм підвищити впевненість у собі, у завтрашній перемозі, у результатах своєї боротьби (Ти воїн, ти козак і ти побореш втому! I ворога здолаєш у бою! Засяє сонце знов, розквітнуть далі, і соловей співатиме в гаю...) (FB, 2020). Таким чином, в українському неінституційному військовому дискурсі простежується взаємозв'язок між зверненням до міфологічної свідомості й копінгом, який розуміється як динамічний процес і розглядається як когнітивні й поведінкові зусилля особистості, спрямовані на зниження впливу стресу (Lazarus, 1993: 142).

Для подальшого дослідження специфіки архетипу Герой в українському неінституційному військовому дискурсі вважаємо за необхідне звернутися до поняття «архетипний образ», яке розглядаємо як форму існування архетипу у свідомості (Jung, 1968). У ході дослідження було відзначено тенденцію відхилення архетипних образів від архаїчного архетипу: у військовому дискурсі домінує модель Героя 3 акцентом на християнську есхатологічну парадигму. Еволюціонування архетипу Герой пов'язано 3 
акцентуацією культурних цінностей: християнство проголошує самовіддану, жертовну любов вищою чеснотою, з'являється герой нового типу - Християнський Святий Воїн (И только вы, на линии огня, гораздо ближе к замыслу Твория) (FB, 2020). Прагненням усіх святих було наслідування Христа (Для вас измена - грех, и трусость - грех, зато за всех несёте общий крест) (FB, 2020), який є втіленням ідеалу добра. Його страждання і смерть трагічні, але за ними відбувається воскресіння (Я к вам ещё вернусь... Вернусь ульљбкой сына, туманом у реки) (FB, 2020). Християнське вчення стверджує, що подвиги бажані Богу. Саме тому вони винагороджуються: героїчна особистість знаходить святість і безсмертя (В раю все наши; Bu - святі героі) (FB, 2020). Мотив принесення жертви, який $\epsilon$ супутній фігурі Героя, формує архетипний образ Героя-праведника. Жертва виступає як наповнення, завершення місії праведника (Я - Двухсотый. Чтоб в детский сад без тебя не шагал ребёнок, чтоб к тебе не вломился ад, с горем, плачем и тьмой воронок) (FВ, 2020), вона приноситься усвідомлено, а кров праведника стає викупною платою за право України залишатися незалежною державою (Як тобі така вира, воїне, чи готовий сплатити не золотом, щзоб довіку ціна за волю ту у душі віддавалася холодом?) (FВ, 2020). Таким чином, модель Праведника стає ядром сучасних архетипних образів Героя, наповнюючи його новими смисловими відтінками.

Під дією традицій, з одного боку, і реальності - з іншого, архетипний образ Героя корелює 3 певними мотивами. Завдяки цьому в українському неінституційному військовому дискурсі домінують дві моделі Героя. Перша модель склалася завдяки американському художньому кінематографові, зокрема фільмам із військовою тематикою. Соціально-політична обстановка в США наприкінці 1990-х - початку 2000-х років, що була пов'язана з новою зовнішньою політикою США, спрямованою на зміцнення статусу єдиної супердержави, поставила проблему створення позитивного мілітаристського настрою в суспільстві. Армія повинна була набути позитивний образ в очах громадськості, і професія військового мала стати престижною. Голлівуд відгукнувся на це замовлення з великим ентузіазмом. У ролі військових знялися секс-символи й сучасні «американські герої». Герой у таких фільмах - русявий, спортивний, із білозубою посмішкою - справжній чоловік, якого любить красива жінка. Війна в таких фільмах зображена гламурною, у традиціях лицарства й шляхетності (Щеголихина, 2013: 332-333). Підтвердженням існування такого типу Героя служать візуальні компоненти українського неінституційного військового дискурсу (фотографії й інтернет-меми), що викладені на сторінках українського сектора соціальних мереж (ілюстрація 1).
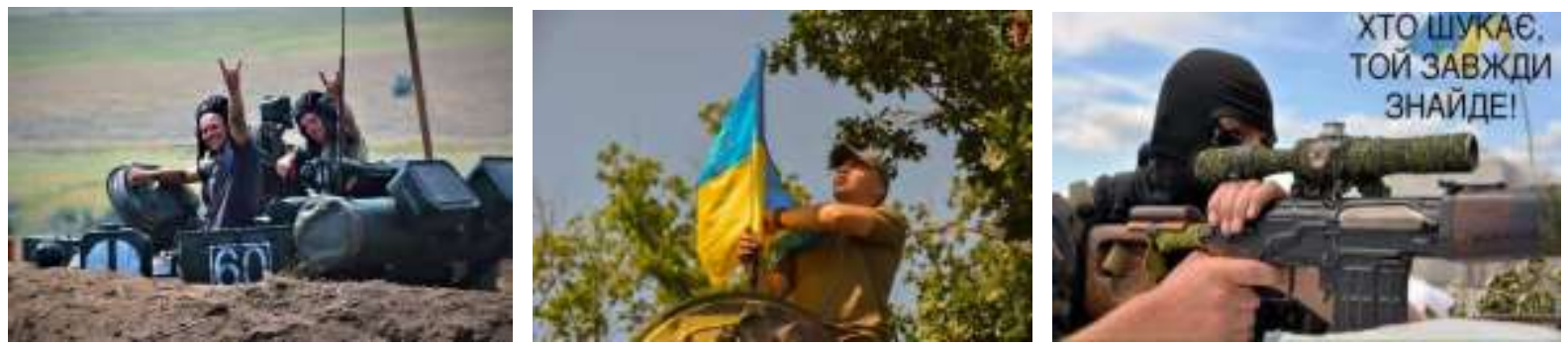

Ілюстрація 1. Актуалізація американської моделі образу Героя (скріншоти запозичені з https://www.facebook.com) 
Образ Героя-надлюдини знаходить своє відображення й у вербальній складовій українського неінституційного військового дискурсу. Він супергерой, подібний міфологічним героям, богам, титанам (Я не людина, я - кіборг; На них залізом плавленим валились сотні тонн, та їх кістки́ не тріснули - не витримав бетон!) (FB, 2020), лицарям (Ведь не бьем мы в безоружных и спины) (FB, 2020), він відважно йде в бій за майбутнє своєї країни й безстрашний у бою (Как сокольв в бою блистали доблестью) (FB, 2020), служить надихаючим прикладом (Знамя высоко вознесём между серыми терриконами. И пришедшие к нам с мечом не увидят нас побеждёнными!) (FB, 2020). Таким чином, образ Героя-надлюдини відрізняється масштабністю й гіперболізацією, він перевершує звичайних людей за своїми можливостями й здібностями. Однак ця модель Героя не тільки не завжди приймається українськими військовослужбовцями, а й може викликати відторгнення й протест (Війна в кіно - ие вибухи і кров, картонний танк, пластмасові гармати, кохання, смерть, медалі, автомати. А у житті: щоб вижити - копати. Знов на білому екрані - літаки, герої як один усі красиві, перлинозубi, втомлено щзасливі. А у житті - замучені та сиві юнаки. Кіно - фантазія на декілька годин, де ти собі вважаєшся героєм, щуо упивається кривавим боєм. А у житті: було нас троє... Уже один) (FB, 2020).

Для українських військових ближче виявилася модель народного Героя, яка $є$ збірним образом української, а не американської культури. Візуальні компоненти українського неінституційного військового дискурсу демонструють образ народного Героя, що є символом національної ідентичності, із яким себе асоціюють бійці і який сприяє усвідомленню людиною власної приналежності до певної нації й держави (ілюстрація 2).
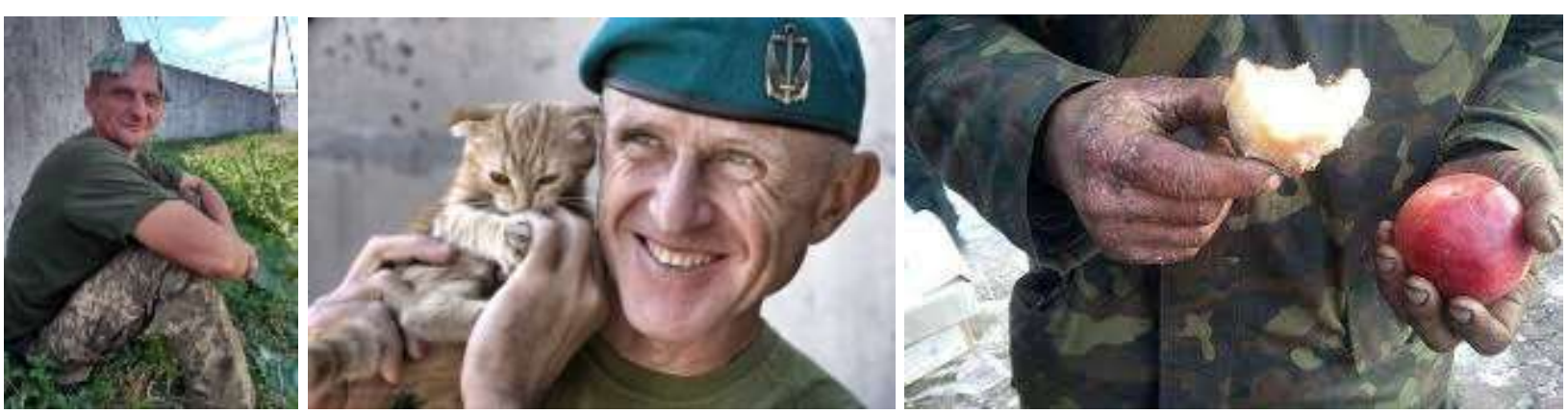

Ілюстрація 1. Актуалізачія моделі народного Героя (скріншоти запозичені з https://www.facebook.com)

Народний герой у військовому дискурсі - структура ментальних компонентів, «під якими розуміються ієрархії культурних конструктів, одні з яких складають ядро культури і притаманні всім їі носіям, інші притаманні тим чи іншим внутрішньо-культурним групам» (Ромах \& Аксенов, 2014). Причому поняття внутрішньокультурної групи для цього дослідження формується в межах існування певного досвіду в проведенні операції Об'єднаних сил. В образі народного Героя актуалізуються риси простого українського роботяги (Сидів в окопі чолов'яга, мобілізований в АТО, звичайний тракторист, трудяга, немає навіть $i$ авто) (FB, 2020), який пішов захищати свою країну (Все вместе пошли защиищать Батьківщину - и старый колхозник Петрович "Седой», и Стёпа Чубенко пацан молодой...) (FB, 2020). Народний герой не є професійним військовим, це мирна людина (Я не родився, щэоби убивати, ламати долі і калічити людей, а народився, щяоб 
ростити й будувати) (FB, 2020), його життя було розколото на дві частини - мирний $\mathrm{i}$ воєнний періоди. Специфікою образу народного Героя $\epsilon$ його реалістичність і контрастність образу супергероя (Он был весь грязный и с лицом небритым, обутый в бериьы, за спиной рюкзак, он кое-где местами был побитый, и на одну из ног мог опираться еле как) (FB, 2020). Така модель склалася завдяки ретроспективному образові народного Героя, пізнім прикладом якого є Тарас Шевченко, і яка сходить до глибокої первісності (Писаренко, 2003: 220). У цьому контексті, на нашу думку, слід згадати Іллю Муромця - одного з головних героїв билин. Його мощі знаходяться в Києво-Печерській лаврі. Ілля Муромець - «скоріше християнин, причому грамотний, за функціями він не стільки воїн, скільки суддя і воєвода. У його особистості переплелися різночасові риси, які не завжди можна відокремити. Він одночасно й конюх Святогора, i селянський/християнський син - «сидень» (каліка), і «старий козак» (голота)» (Козловский, 2016: 177). Ф. Буслаєв зазначав: «Велика особистість Іллі Муромця, в основних своїх обрисах, може бути, нагадувала ідеальні типи напівбогів, руйнівника всього шкідливого на землі... Але в епоху історичну, коли склався цикл Владимиров, Ілля Муромець став могутнім представником сил простого народу» (Буслаев, 2015).

\section{Висновки.}

Міфологічний архетип Героя-рятівника лежить в основі сюжетних моделей, що представлені в українському неінституційному військовому дискурсі. У дискурсі простежується стійкість міфологічного сюжету. Так, були відзначені типові дієві етапи одіссеї міфологічного Героя: початок пригод міфологічного Героя провокує катастрофа, яка $\epsilon$ наслідком злочинних дій недоброзичливців; Герой відправляється в подорож із метою відновлення порушеної гармонії; злозичливці діють усупереч, але Герой проходить шлях випробувань і завойовує свою нагороду. Його тріумф може бути представлений як визволення свого народу від тирана. Звернення до міфологічного сюжету несе прагматичне навантаження: для подолання стресу військовим необхідна впевненість у щасливому розв'язанні проблемної ситуації (військового конфлікту на Сході України), і міфологічний Герой допомагає їм підвищити впевненість у собі. Таким чином, в українському неінституційному військовому дискурсі простежується взаємозв'язок між зверненням до міфологічної свідомості й копінг-стратегіями. У ході дослідження було відзначено тенденцію відхилення архетипних образів від архаїчного архетипу: у військовому дискурсі домінує модель Героя з акцентом на християнську есхатологічну парадигму. Мотив принесення жертви, який супутній фігурі Героя, формує архетипний образ Героя-праведника. В українському неінституційному військовому дискурсі домінують дві моделі Героя. Перша модель характеризується масштабністю й гіперболізацією. Це образ Героя-надлюдини, що містить у собі риси супергероя, подібного міфологічним героям, богам, титанам. Однак ця модель Героя не тільки не завжди приймається українськими військовими, а й може викликати відторгнення й протест. Друга модель є збірним образом народної, а не елітарної культури. Його відрізняють реалістичність і контрастність образу супергероя.

Отримані результати дослідження мають безпосереднє відношення до соціальних і соціально-психологічних результатів трансформацій, які відбуваються в суспільстві й можуть бути використані для подальшого розвитку теоретико-методологічних підходів до дослідження структури, форми й механізмів конструювання національної ідентичності й формування національно орієнтованих цінностей. 


\section{Література}

Боровицька, О.М. (2013). Архетипна феноменологія як фундаментальна методологія дослідження психічних універсалій. Науковий часопис НПУ імені М.П. Драгоманова, $40,80-86$.

Бугерко, Я.М. (2013). Зв’язок архетипу із духовно-ментальними факторами формування психіки. Науковий часопис наиіонального педагогічного університету імені М.П. Драгоманова, 40, 86-92.

Буслаев, Ф. И. (2015). Исторические очерки русской народной словесности и искусства. Москва: Издательство В. Секачев.

Воеводина, Л.Н. (2012). Структура мифологического образа и социальная драматургия. Вестник МГУКИ, 1 (45), 50-55.

Гордійчук, О.О. (2018). Архетипи української ментальності: соціально-філософський аналіз. Вісник Житомирського державного університету імені Івана Франка, 1 (84), $15-19$.

Гоц, Л.С. (2017). Архетип і архетипний образ: проблеми термінології у дослідженнях культури. Вісник Найіональної академії керівних кадрів культури і мистецттв, 4, 5257.

Доброродний, Д.Г. (2009). Психоанализ как методологический проект в социальногуманитарном познании. Теоретический журнал «Credo new», 2, 150-168.

Иванов, А.Г. (2019). Мифологема героя в структуре социального мифа. Вестник Томского государственного университета, 441, 80-88. DOI: 10.17223/15617793/441/11.

Ищенко, Н.А. (2007). Военный дискурс и дискурсивное измерение войны. Культура народов Причерноморья. Филологические науки, 116, 22-24.

Касавин, И.Т. (2007). Дискурс-анализ и его применение в психологии. Bonpocbl психологии, 6, 97-119.

Кожина, М.Н. (2002). Целый текст как объект стилистики текста. Речеведение $u$ функииональная стилистика: вопросы теории: избр. труды. Пермь: Перм. Ун-т, ПСИ, ПССГК.

Козловский, С.В. (2016). Илья Муромец и его время: историография и перспективы изучения образа былинного героя. Палеоросия. Древняя Русь во времени, в личностях, в идеях, 5, 177-189.

Лазарев, В.А., Ласкова, М.В. (2020). Лингвостилистические и интерпретационные особенности англоязычных милитарных сленгизмов в неофициальном милитарном дискурсе. Известия Южного федерального университета, 2, 103-111. DOI: 10.18522/1995-0640-2020-2-103-111.

Огієнко, І.С. (2012). Дискурс та підходи до його аналізу: погляди на проблему сучасних англомовних дослідників. Наукові записки Наиіонального університету «Острозька академія», 23, 98-102.

Писаренко, Ю. (2003). Архаїчні витоки образу «народного героя». Соціум. Альманах соиіальної історії, 2, 209-222.

Процик, І.В. (2009). Поняття архетипу в науковій літературі: генетико-теоретичний аспект. Вісник Запорізького національного університету, 2, 56-67.

Ромах, О.В., Аксенов, Ф.О. (2014). Антропологические обоснования символа «Народного героя» в системе координат культуры. Международный журнал экспериментального образования, 3-1, 70-74. 
Савелюк, Н. (2017). Психологія розуміння релігійного дискурсу. Київ: КНТ.

Склейнис, В.А. (2019). Архетипические аспекты динамики смысловых структур. Психолог, 2, 1-8. DOI: 10.25136/2409-8701.2019.2.28386.

Суравнева, И.М., Федоров, В.В. (2008). Феномен героизма. Москва: Издательство ЛКИ.

Уланов, А.В. (2014). Военный дискурс русского языка XIX - начала XX в. в спектре языковой эволючии. Омск: Издательство «Литера».

Шевченко, А.С. (2012). Театральный дискурс: структура, жанры, особенности лингвистической репрезентаџии: автореф. дисс... канд. филол. Санкт-Петербург.

Щеголихина, С.Н. (2013). Образ американского военного в художественных фильмах Голливуда. Метаморфозы истории, 322-351.

Юрій, М., Алексієвець Л. (2017). Архетип і ментальність через призму історії. УкраїнаЄвропа-Світ. Міжнародний збірник наукових пращь, 19, 16-24.

Яценко, Т.С. (2011). До проблеми пізнання індивідуальної неповторності архетипної символіки. Науковий часопис НПУ імені М.П. Драгоманова, 33(57), 15-27.

Campbell, J. (1949). The hero with a thousand faces. New York, NY: Pantheon Books.

Dirven, R., Polzenhagen, F., Wolf, H.-G. (2005). Cognitive Linguistics, Ideology, and Critical Discourse Analysis. Handbook of Cognitive Linguistics. Oxford: Oxford University Press. DOI: 10.1093/oxfordhb/9780199738632.013.0047.

Guo, A., \& Ma, J. (2018). Archetype-Based Modeling of Persona for Comprehensive Personality Computing from Personal Big Data. Sensors (Basel, Switzerland), 18(3), 684. DOI: $10.3390 / \mathrm{s} 18030684$.

Heer, H., Manoschek, W., Pollak, A., Wodak, R. (2003). Wie Geschichte gemacht wird. Erinnerungen an Wehrmacht und Zweiten Weltkrieg. Vienna: Czernin.

Jorgensen, M., \& Phillips, L. (2002). Discourse analysis as theory and method. London: Sage Publications.

Jung, C. G. (1968). The archetypes and the collective unconscious. 2nd ed (R. F. Hull, Trans.). Princeton, NJ: Princeton University Press.

Keil, F. C. (2006). Explanation and Understanding. Annu Rev Psychol, 57, 227-254. DOI: 10.1146/annurev.psych.57.102904.190100.

Lazarus, S. (1993). Coping Theory and Research: Past, Present, and Future. Psychosomatic Medicine, 55, 234-247.

Mark, M., \& Pearson, C. (2001). The hero and the outlaw: building extraordinary brands through the power of archetypes. New York: McGraw-Hill.

Martin, R. (1990). Wright on Explanation and Understanding: An Appraisal. History and Theory, 29(2), 205-233. DOI: 10.2307/2505226.

McAdams, D.P. (2008). Personal narratives and the life story. In O.P. John, R.W. Robins, \& L.A. Pervin (Eds.). Handbook of personality: Theory and research (pp. 242-262). The Guilford Press.

Neumann, E. (1954). The origins and history of consciousness. Princeton University Press.

Ruiz Ruiz, J. (2009). Sociological Discourse Analysis: Methods and Logic. Forum Qualitative Sozialforschung / Forum: Qualitative Social Research, 10 (2). DOI: 10.17169/fqs10.2.1298.

Schlegel, R.J., Hick, s J.A., King, L.A., Arndt, J. (2011). Feeling Like You Know Who You Are: Perceived True Self-Knowledge and Meaning in Life. Personality and Social Psychology Bulletin, 37 (6), 745-756. DOI: 10.1177/0146167211400424. 
Shadraconis, S. (2013) Leaders and Heroes: Modern Day Archetypes. LUX: A Journal of Transdisciplinary Writing and Research from Claremont Graduate University, 3 (1). DOI: 10.5642/LUX.201303.15.

Teun, A. van Dijk (2014). Discourse-Cognition-Society. Current State and Prospects of the Socio-Cognitive Approach to Discourse. In C. Hart and P. Cap (Eds.). Contemporary Critical Discourse Studies (pp. 121-146). London: Bloomsbury Academic.

\section{References}

Borovyczka, O.M. (2013). Arxetypna fenomenologiya yak fundamental na metodologiya doslidzhennya psyxichnyx universalij [Archetypal phenomenology as a fundamental methodology for the study of mental universals]. Naukovyj chasopys NPU imeni M.P. Dragomanova - Scientific journal M.P. Drahomanov National Pedagogical University, 40, 80-86 [In Ukrainian].

Bugerko, Ya.M. (2013). Zvyazok arxetypu iz duxovno-mentalnymy faktoramy formuvannya psyxiky [The connection of the archetype with the spiritual and mental factors of the psyche formation]. Naukovyj chasopys nacionalnogo pedagogichnogo universytetu imeni M.P. Dragomanova - Scientific journal M.P. Drahomanov National Pedagogical University, 40, 86-92 [In Ukrainian].

Buslaev, F.I. (2015). Istoricheskie ocherki russkoj narodnoj slovesnosti i iskusstva [Historical sketches of Russian folk literature and art]. Moskva: Izdatelstvo V. Sekachev [In Russian].

Campbell, J. (1949). The hero with a thousand faces. New York, NY: Pantheon Books [in English].

Dirven, R., Polzenhagen, F., Wolf, H.-G. (2005). Cognitive Linguistics, Ideology, and Critical Discourse Analysis. Handbook of Cognitive Linguistics. Oxford: Oxford University Press. DOI: 10.1093/oxfordhb/9780199738632.013.0047 [in English].

Dobrorodnij D.G. (2009). Psikhoanaliz kak metodologicheskij proekt v social no-gumanitarnom poznanii [Psychoanalysis as a methodological project in social and humanitarian knowledge]. Teoreticheskij zhurnal «Credo new», 2, 150-168 [in Russian].

Gocz, L.S. (2017). Arxetyp i arxetypnyj obraz: problemy terminologiyi u doslidzhennyax kultury [Archetype and archetypal image: problems of terminology in cultural research]. Visnyk Nacionalnoyi akademiyi kerivnyx kadriv kultury $i$ mystecztv - Bulletin of the National Academy of Management of Culture and Arts, 4, 52-57 [In Ukrainian].

Gordijchuk, O.O. (2018). Arxetypy ukrayinskoyi mentalnosti: socialno-filosofskyj analiz [Archetypes of Ukrainian mentality: social-philosophical analysis]. Visnyk Zhytomyrskogo derzhavnogo universytetu imeni Ivana Franka - Bulletin of Ivan Franko Zhytomyr State University, 1 (84), 15-19 [In Ukrainian].

Guo, A., \& Ma, J. (2018). Archetype-Based Modeling of Persona for Comprehensive Personality Computing from Personal Big Data. Sensors (Basel, Switzerland), 18(3), 684. DOI: 10.3390/s18030684 [in English].

Heer, H., Manoschek, W., Pollak, A., Wodak, R. (2003). Wie Geschichte gemacht wird. Erinnerungen an Wehrmacht und Zweiten Weltkrieg. Vienna: Czernin [in English].

Ishenko, N. A. (2007). Voennyj diskurs i diskursivnoe izmerenie vojny [Military discourse and the discursive dimension of war]. Kultura narodov Prichernomorya. Filologicheskie nauki - Culture of the Black Sea peoples. Philological sciences, 116, 22-24 [in Russian].

Ivanov, A.G. (2019). Mifologema geroya v strukture soczialnogo mifa [The mythology of the hero in the structure of social myth]. Vestnik Tomskogo gosudarstvennogo universiteta - 
Bulletin of Tomsk State University, 441, 80-88. DOI: 10.17223/15617793/441/11 [In Russian].

Jorgensen, M., \& Phillips, L. (2002). Discourse analysis as theory and method. London: Sage Publications [in English].

Jung, C. G. (1968). The archetypes and the collective unconscious. 2nd ed (R. F. Hull, Trans.). Princeton, NJ: Princeton University Press [in English].

Kasavin, I.T. (2007). Diskurs-analiz i ego primenenie v psikhologii [Discourse analysis and its application in psychology]. Voprosy psikhologii - Issues of psychology, 6, 97-119 [In Russian].

Keil, F.C. (2006). Explanation and Understanding. Annu Rev Psychol, 57, 227-254. DOI: 10.1146/annurev.psych.57.102904.190100 [In English].

Kozhina, M.N. (2002). Czelyj tekst kak obekt stilistiki teksta [Whole text as an object of text stylistics]. Rechevedenie i funkczionalnaya stilistika: voprosy teorii: izbr. trudy. Perm: Perm. Un-t, PSI, PSSGK [In Russian].

Kozlovskij, S.V. (2016). Ilya Muromecz i ego vremya: istoriografiya i perspektivy izucheniya obraza bylinnogo geroya [Ilya Muromets and his time: historiography and prospects for studying the image of an epic hero]. Paleorosiya. Drevnyaya Rusvo vremeni, $v$ lichnostyakh, videyakh - Paleorosia. Ancient Russia in time, in personalities, in ideas, 5, 177-189 [In Russian].

Lazarev, V.A., Laskova, M.V. (2020). Lingvostilisticheskie i interpretaczionnye osobennosti angloyazychnykh militarnykh slengizmov v neoficzialnom militarnom diskurse [Linguistic and interpretive features of English-language military slangisms in the unofficial military discourse]. Izvestiya Yuzhnogo federalnogo universiteta, 2, 103-111. DOI: 10.18522/19950640-2020-2-103-111 [In Russian].

Lazarus, S. (1993). Coping Theory and Research: Past, Present, and Future. Psychosomatic Medicine, 55, 234-247 [In English].

Mark, M., \& Pearson, C. (2001). The hero and the outlaw: building extraordinary brands through the power of archetypes. New York: McGraw-Hill [in English].

Martin, R. (1990). Wright on Explanation and Understanding: An Appraisal. History and Theory, 29(2), 205-233. DOI: 10.2307/2505226 [In English].

McAdams, D.P. (2008). Personal narratives and the life story. In O.P. John, R.W. Robins, \& L.A. Pervin (Eds.). Handbook of personality: Theory and research (pp. 242-262). The Guilford Press [in English].

Neumann, E. (1954). The origins and history of consciousness. Princeton University Press [in English].

Ogiyenko, I.S. (2012). Dyskurs ta pidxody do jogo analizu: poglyady na problemu suchasnyx anglomovnyx doslidnykiv [Discourse and approaches to its analysis: views on the problem of contemporary English-speaking researchers]. Naukovi zapysky Nacional'nogo universytetu «Ostrozka akademiya» - Scientific Notes of Ostroh Academy, 23, 98-102 [in Ukrainian].

Procyk, I.V. (2009). Ponyattya arxetypu v naukovij literaturi: genetyko-teoretychnyj aspect [The concept of archetype in the scientific literature: genetic and theoretical aspect]. Visnyk Zaporizkogo nacionalnogo universytetu - Bulletin of Zaporizhia National University, 2, 56 - 67 [in Ukrainian].

Pysarenko, Yu. (2003). Arxayichni vytoky obrazu «narodnogo geroya» [Archaic origins of the image of the "people's hero"]. Socium. Almanax socialnoyi istoriyi - Society. Almanac of Social History, 2, 209-222 [in Ukrainian]. 
Romakh, O.V., Aksenov, F.O. (2014). Antropologicheskie obosnovaniya simvola «Narodnogo geroya» $\mathrm{v}$ sisteme koordinat kultury [Anthropological substantiation of the symbol of the "People's Hero" in the cultural coordinate system]. Mezhdunarodnyj zhurnal eksperimentalnogo obrazovaniya - International Journal of Experimental Education, 3-1, 70-74 [In Russian].

Ruiz Ruiz, J. (2009). Sociological Discourse Analysis: Methods and Logic. Forum Qualitative Sozialforschung / Forum: Qualitative Social Research, 10 (2). URL: https://www.qualitative-research.net/index.php/fqs/article/view/1298/2882. 10.17169/fqs-10.2.1298 [in English].

Savelyuk, N. (2017). Psikhologiya rozuminnya religijnogo diskursu [Psychology of understanding religious discourse]. Kiyiv: KNT [In Ukrainian].

Schlegel, R.J., Hick, s J.A., King, L.A., Arndt, J. (2011). Feeling Like You Know Who You Are: Perceived True Self-Knowledge and Meaning in Life. Personality and Social Psychology Bulletin, 37 (6), 745-756. DOI: 10.1177/0146167211400424 [in English].

Shadraconis, S. (2013) Leaders and Heroes: Modern Day Archetypes. LUX: A Journal of Transdisciplinary Writing and Research from Claremont Graduate University, 3 (1). DOI: 10.5642/LUX.201303.15 [in English].

Shevchenko, A.S. (2012). Teatralnyj diskurs: struktura, zhanry, osobennosti lingvisticheskoj reprezentacii [Theatrical discourse: structure, genres, features of linguistic representation]. (Candidate dissertation). Sankt-Peterburg [In Russian].

Shhegolikhina, S.N. (2013). Obraz amerikanskogo voennogo v khudozhestvennykh filmakh Gollivuda [The image of the American soldier in Hollywood feature films]. Metamorfozy istorii - Metamorphoses of history, 322-351[in Russian].

Sklejnis, V.A. (2019). Arkhetipicheskie aspekty dinamiki smyslovykh struktur [Archetypal aspects of the semantic structures dynamics]. Psikholog - Psychologist, 2, 1-8. DOI: 10.25136/2409-8701.2019.2.28386 [In Russian].

Suravneva, I.M., Fedorov, V.V. (2008). Fenomen geroizma [The phenomenon of heroism]. Moskva: Izdatelstvo LKI [In Russian].

Teun A. van Dijk (2014). Discourse-Cognition-Society. Current State and Prospects of the Socio-Cognitive Approach to Discourse. In C. Hart and P. Cap (Eds.). Contemporary Critical Discourse Studies (pp. 121-146). London: Bloomsbury Academic [in English].

Ulanov, A.V. (2014). Voennyj diskurs russkogo yazyka XIX - nachala XX v.v spektre yazykovoj evolyucii [The military discourse of the Russian language of the 19th-early 20th centuries in the spectrum of language evolution]. Omsk: Izdatelstvo «Litera» [in Russian].

Voevodina, L.N. (2012). Struktura mifologicheskogo obraza i soczialnaya dramaturgiya [The structure of the mythological image and social drama]. Vestnik MGUKI-Bulletin of the Moscow State University of Culture and Arts, 1 (45), 50-55 [In Russian].

Yacenko, T.S. (2011). Do problemy piznannya indyvidualnoyi nepovtornosti arxetypnoyi symvoliky [To the problem of individual uniqueness of archetypal symbolism]. Naukovyj chasopys NPU imeni M. P. Dragomanova - Scientific journal M.P. Drahomanov National Pedagogical University, 33 (57), 15-27 [in Ukrainian].

Yurij, M., Aleksiyevecz L. (2017). Arxetyp i mentalnist cherez pryzmu istoriyi [Archetype and mentality through the prism of history]. Ukrayina-Yevropa-Svit. Mizhnarodnyj zbirnyk naukovyx pracz - Ukraine-Europe-Svit. International collection of scientific works, 19, 16 -24 [in Ukrainian].

\section{Sources}


FB (Facebook). “Військова служба - Military service”. Retrieved from https://www.facebook.com/groups/655994877875713/.

FB (Facebook). “Збройні Сили України - Armed Forces of Ukraine”. Retrieved from https://www.facebook.com/groups/ukr.military/.

\title{
АРХЕТИПІЧНІ АСПЕКТИ ОБРАЗУ ГЕРОЯ В СУЧАСНОМУ УКРАЇНСЬКОМУ НЕІНСТИТУЦЙНОМУ ВІЙСЬКОВОМУ ДИСКУРСІ
}

\author{
Тетяна ХРАБАН, \\ кандидат філологічних наук, \\ завідувач кафедри іноземних мов \\ Військового інституту телекомунікацій та інформатизаиії \\ (м. Київ, Україна)
}

\begin{abstract}
Анотація
Мета статmi - дослідження специиріки архетипічних аспектів образу Героя в сучасному українському неінституційному військовому дискурсі.

Матеріали й методи дослідження. У дослідженні було використано дискурсаналіз, спрямований на виявлення характеристик архетипічних образів $i$ мотивів. Застосування психоаналітичної інтерпретації як особливої пізнавальної установки, найбільш характерними рисами якої є акцентуація смислів і допущення самодостатності пережсивання, або досвіду, спрямувало увагу на закладену в тексті символіку несвідомого, універсальні значення й психологічні механізми. Матеріалом для статті послужили текстові фрагменти, фотографії й коментарі до них загальним обсягом 912 одинииь, які розміщені протягом 2020 року на сторінках груп соиіальної мережі Facebook «Military service - Військова служба», «Збройні Сили Украӥни».

Результати й дискусії. Міфологічний архетип Героя-рятівника лежить в основі сюжетних матрииь, щзо представлені в українському неінституційному військовому дискурсі. У дискурсі простежується стійкість міфологічного сюжету. Так, були відзначені типові дієві етапи одіссеї міфологічного Героя: початок пригод міфологічного Героя провокує катастрофа, яка є наслідком злочинних дій недоброзичливиів; Герой відправлясться в подорож із метою відновлення порушеної гармонї; злозичливиі діють усупереч, але Герой проходить илях випробувань $і$ завойовує свою нагороду. Його тріумф може бути представлений як визволення свого народу від тирана. Звернення до міфологічного сюжету несе прагматичне навантаження: для подолання стресу військовим необхідна впевненість у щзасливому розв'язанні проблемної ситуації (військового конфлікту на Сході Украӥни), і міфологічний Герой допомагає їм підвищити впевненість у собі. Таким чином, в українському неінституційному військовому дискурсі простежується взаємозв'язок між зверненням до міфологічної свідомості й копінгстратегіями. У ході дослідження було відзначено тенденцію відхилення архетипних образів від архаїчного архетипу: у військовому дискурсі домінує модель Героя з акиентом на християнську есхатологічну парадигму. Мотив принесення жертви, який супутній фігурі Героя, формує архетипний образ Героя-праведника.

Висновки. В українському неінституиійному військовому дискурсі домінують дві моделі Героя. Перша модель характеризується масштабністю й гіперболізацією. Це
\end{abstract}


образ Героя-надлюдини, щзо поєднує в собі риси святого й лицаря, супергероя, подібного міфологічним героям, богам, титанам. Друга модель є збірним образом украӥнської народної культури. В образі народного Героя актуалізуються риси трудівника, який не $\epsilon$ професійним військовим, це мирна людина. Цей архетипний образ відрізняють реалістичність $і$ контрастність образу супергероя.

Ключові слова: архетип Герой, архетипний образ, неінституційний військовий дискурс.

Submitted to the editor -16.04 .2021$

Reviewed-23.05.2021

Accepted for printing - 02.07.2021

Подано до редакиії-16.04.2021

Рецензовано - 23.05.2021

Прийнято до друку - 02.07.2021 